\title{
European Integration and the Effects of Country Size on Growth
}

Jörg König

Georg-August-University of Goettingen \& Stiftung Marktwirtschaft, Berlin, Germany

\begin{abstract}
Does the size of a country affect its economic growth rate? Theory suggests that the existence of a national scale effect is favouring large countries and that small countries may overcome the impediments of smallness once their markets become internationally more integrated. So far, empirical evidence of a distinct impact of country size on economic growth is rather limited. The present study sheds light on this impact from a European perspective. Country size indeed correlates with economic growth and European economic integration enhances the convergence process of the countries. It is further shown that the impact of size varies according to a country's individual level of economic integration, suggesting that the long-term economic growth path is characterized by multiple transition points. This finding is particularly important given the prevailing imperfections of the European Union Single Market and the increasing number of small European Union member states.
\end{abstract}

JEL Classifications: C23, F15, F43, O52

Keywords: Country Size, European Economic Integration, Economic Growth, Economic Convergence, Panel Data, Fixed Effects

\footnotetext{
* Corresponding Author: Jörg König; Georg-August-University of Goettingen, Platz der Goettinger Sieben 3, 37073 Goettingen, Germany; Tel: +49 551397412, Fax: +49 551397093, E-mail: joerg.koenig@uni-goettingen.de. 


\section{Introduction}

In the past two decades, the European Union (EU) has grown remarkably through the accession of new member states. Since the launch of the EU Single Market in 1993, the number of countries more than doubled from 12 to $28 \mathrm{EU}$ member states. Interestingly, it was mainly the small countries that entered the EU in the last enlargement rounds. As illustrated in Figure 1, most of the new member states show quite low levels of population where the smallest being Malta with less than 500,000 people, whereas the older member states mostly belong to the large EU countries.

\section{Figure 1. Population of EU member states}

(in Millions, 2012)

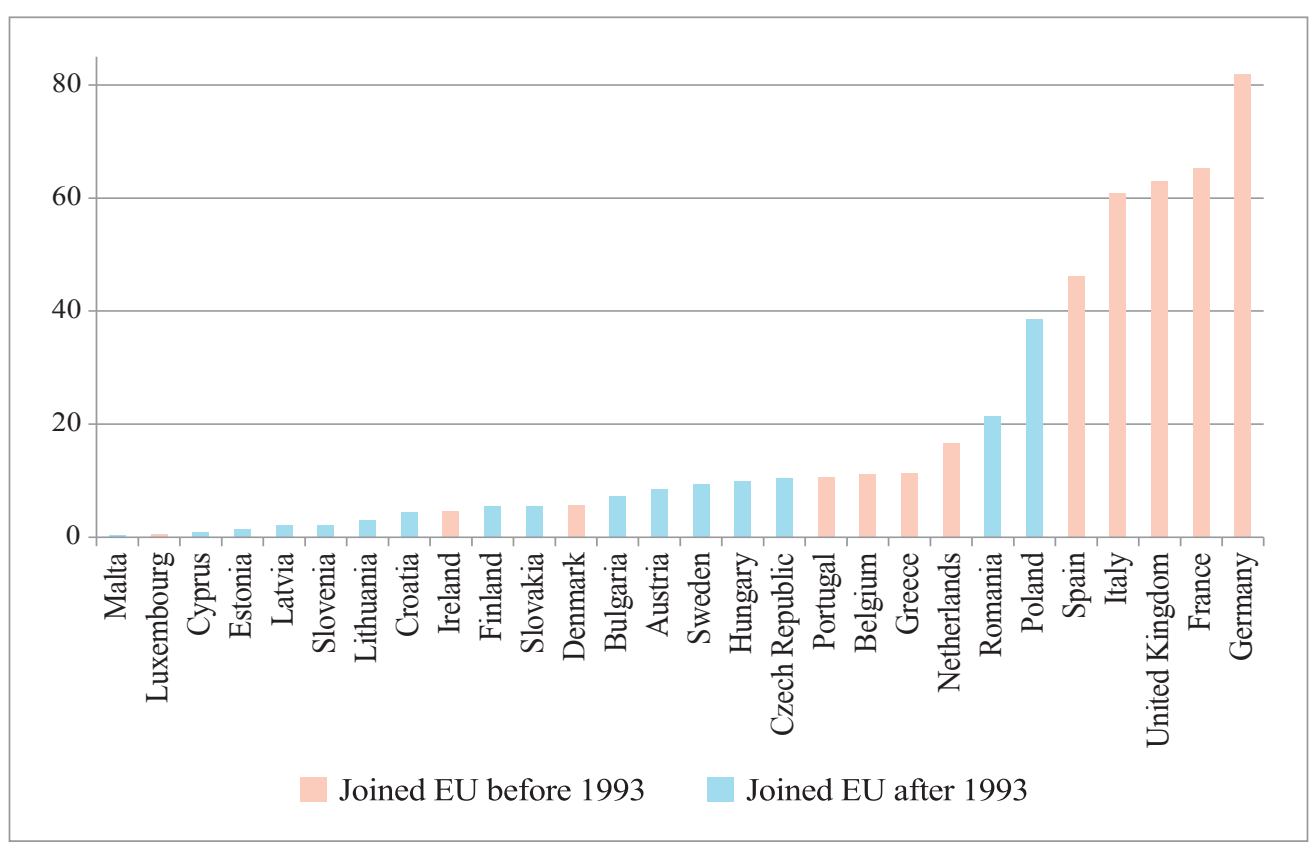

(Source) Eurostat database.

The increasing number of small EU countries might suggest that EU membership provides some economic and political advantages that are particularly beneficial to small countries. As first discussed by Robinson (1960), and later taken up by Alesina and Spolaore (2003), it can be argued that small economies are initially weaker than their larger counterparts in general. This is mainly due to their limitation in factor endowments 
and economies of scale. However, it is also argued that increasing economic integration can eventually compensate for the initial impediments of smallness. ${ }^{1}$ In the case of the EU, free access to the EU Single Market should push the small economies to a higher level. Within this process, the induced economic growth effects should then be relatively larger in small countries.

Figure 2 encourages this view. Over the past 20 years, the average annual economic growth rates of small EU countries generally exceeded the growth rates of the large ones. During only the first years of the global financial crisis (2008 and 2009), the group of small countries faced a relatively larger decline in growth rates, which can be explained by their larger international dependency. On average, the group of small states grew by $2.6 \%$ per year, whereas the large countries only grew by $1.4 \%$. This leads to the following question: Does the size of a country (and the level of EU integration) really affect its economic growth rate?

Figure 2. Economic growth of EU members

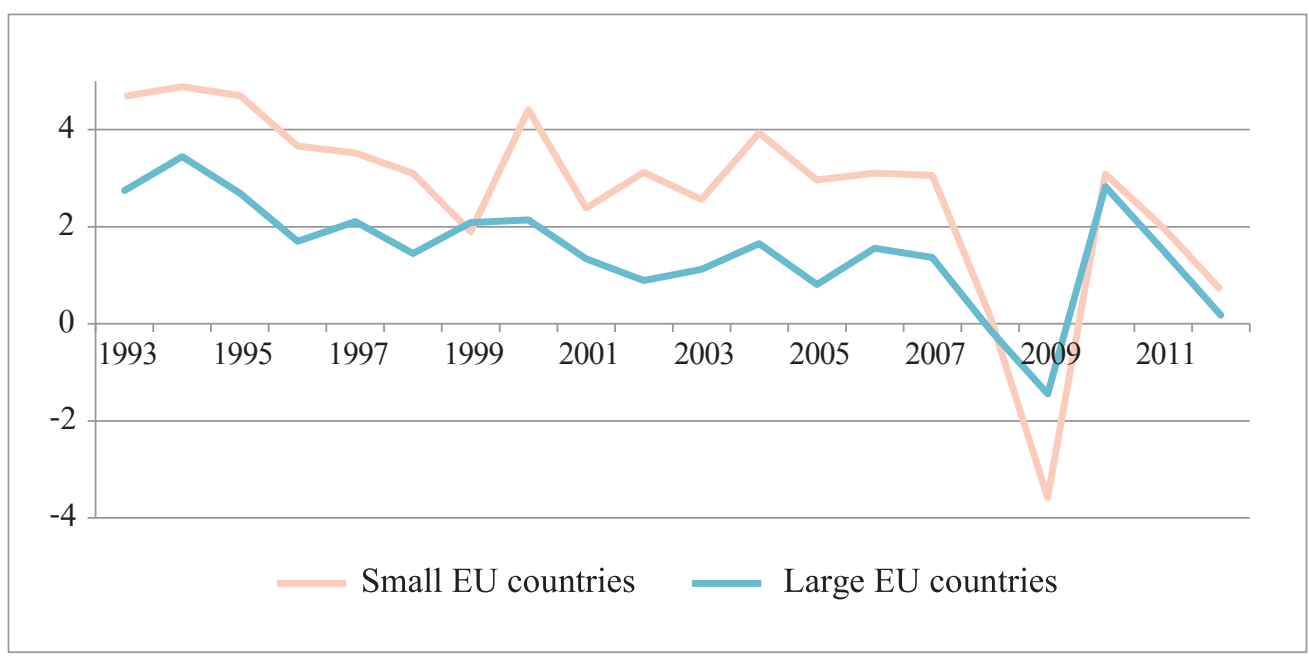

(Notes) The figure shows the annual percentage growth rate of real GDP per worker (15 64 years, 2005 prices). The group of small countries consists of the 21 smallest EU countries (from Malta to Romania, without Croatia) while the group of large countries consists of the 6 largest EU countries (from Poland to Germany).

(Source) Eurostat database.

The aim of this paper is to investigate this question. We analyze empirically whether

\footnotetext{
${ }^{1}$ For a recent analysis of the mechanisms through which openness may affect growth, see Veeramani (2014).
} 
the size of a country contains statistically significant explanatory power to the economic success of the EU countries. The paper is contributing to the existing literature as it combines two related lines of empirical research that investigate the effects of country size on economic performance differently. Whereas the first line tests for a national scale effect on economic growth in general (Easterly and Kraay 2000, Alesina et al. 2005, Rose 2006), the second line of research focuses on the changes in the small members' export ratios while enlarging a trade bloc (the so-called Casella effect; see Casella 1996, and Badinger and Breuss 2006 and 2009). Both lines of research deliver highly mixed empirical results when markets become internationally more integrated. Statistically significant and insignificant, as well as positive and negative, impacts on growth are found. The study at hand elaborates on some explanations for this phenomenon from a European perspective. The deepening and widening of the EU over the last 20 years provide an excellent research possibility in that regard.

We proceed as follows. The next section reviews the main theoretical thoughts on economic growth patterns of small countries in the light of European economic integration. The article then goes on to test whether economic convergence has occurred among the EU members over the last two decades in Section III. The detection of economic convergence is important when the expected positive effects of increased European integration on small countries should hold. Subsequently, in Section IV the effects of country size on economic growth are estimated and some robustness checks are performed. The final section summarizes the main findings and discusses some policy implications.

\section{European Integration on Small Countries}

"International trade and/or economic union can offset the disadvantages of smallness" (Scitovsky 1960, p. 284). By expanding their small domestic markets to the large EU Single Market, small countries get access to capital and labour from the other EU partner countries. Due to the expectation of high marginal returns, incentives for investment and migration increase. This promotes a more efficient allocation of production factors. Additionally, capital inflow usually implies a transfer of technology leading to growth promoting industrial structures in those countries (De Mello 1999). The removal of 
barriers to trade within the union further reduces the transaction costs and expands market potentials for both the consumers and producers. More specifically, access to a larger market decreases the small countries' dependence on few trade partners and reduces their vulnerability to idiosyncratic shocks. Domestic firms become more confronted with external competition and have to produce more efficiently. In turn, this leads to lower consumption prices, better product and process innovation, and larger product variety. In a nutshell, higher productivity is achieved due to a large change in relative prices (Armstrong and Read 2003), leading to a catching-up process of the small economy.

Diagram A in Figure 3 displays such an economic convergence process for two economies over time. It is assumed that the domestic market of the large country remains mostly unaffected by external factors. Thus, its per capita economic growth rate is, on average, constant over time. In congruence with neoclassical growth theory, it could be assumed that the large economy has reached its long run steady state in which the economic growth rate is constant by definition. The small economy starts out being poorer than the large economy in period $t_{0}$. Because of higher marginal returns, the small economy is able to grow economically faster. Thus, the initial dispersion of per capita income between the economies steadily decreases as time and economic integration increase $\left(t_{0+T}\right)$.

Figure 3. Scenarios of economic convergence and divergence

\section{a) Convergence}

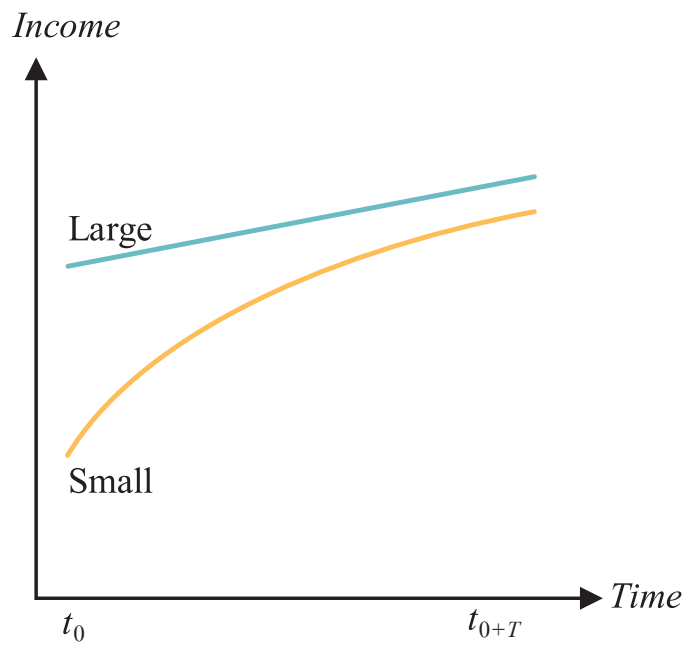




\section{b) Divergence}

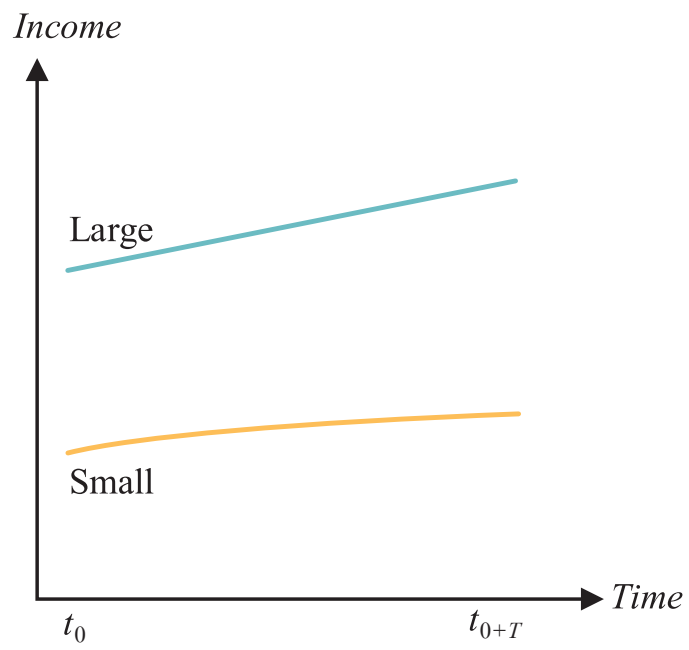

\section{c) Lagged Convergence}

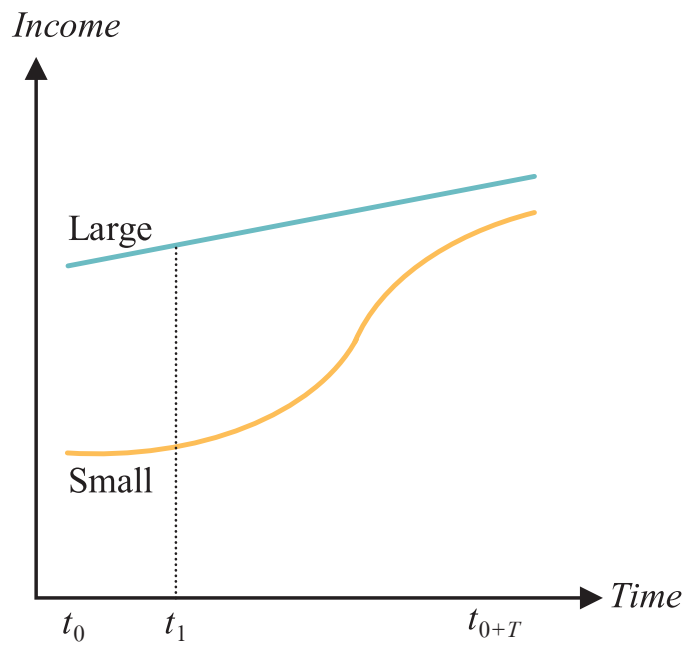

(Note) Diagrams A and B are remodelled from Sala-i-Martin (1996), while Diagram C is its own presentation.

However, the EU Single Market is far from being complete. Especially, barriers to trade in services still exist. This becomes particularly apparent in the financial service sector (e.g., security trading regulations), in which the so-called politics of competing advocacy coalitions restricts further liberalization (Howarth and Sadeh 2011). The 
incompletion of the Single Market is also reflected in the prevailing differences between the de jure regulations and de facto practices of the acquis communautaire. Ongoing infringement proceedings with regard to competition law demonstrate the members' unwillingness to free the markets, leading to a quite heterogeneous community in that regard (König and Ohr 2013). Additionally, given the different cultures and languages in the EU, labour is greatly inflexible and intra-European migration is highly unbalanced between the member states. Migration is rather one-sided from Eastern to Western Europe (Zimmermann 2009). Furthermore, consumption baskets and investment portfolios still contain a larger share of home products and equity (Balta and Delgado 2009, Pacchioli 2011). This home bias reduces the efficient allocation of resources among the member states and increases the small member states' vulnerability to exogenous shocks (Furceri and Karras 2007). Thus, the incompletion of the EU Single Market is expected to have a larger negative effect on the small countries' productivity, whereas the large countries can compensate for those effects with their comparative advantage in absolute factor endowments, immense ability to make use of economies of scale, and capacity to internalize external effects. The small member states are then less capable to follow an economic catching-up process.

Furthermore, economic divergence can also be explained by endogenous growth theory (Romer 1986, Lucas 1988) and the new economic geography model (Krugman 1991). Due to the absence of diminishing returns to capital, in contrast to the neoclassical models, large countries are always more competitive and can exploit the removal of market imperfections better than small countries. Further, large countries gain more from market integration, not only in absolute but in relative terms. The same applies to the models of new economic geography, in which spatial concentration of economic activities and reduced transaction costs are leading to agglomeration effects that favour the economy whose domestic market is more attractive. Due to centripetal forces, the large economy attracts a larger share of firms and along with it capital and labour. For the small country, the loss of physical and human capital, i.e., brain drain, lowers its economic growth rate. This divergence effect is illustrated by Diagram B in Figure 3. Here, the economic gap between the two economies is becoming larger in the end.

Moreover, there could be at least one other scenario. New economic geography also states that the process of divergence may change towards a process of convergence after a certain amount of time. ${ }^{2}$ Remittances of the migrated workers help to finance the

\footnotetext{
${ }^{2}$ See the bell-shaped curve argument in Tabuchi and Thisse (2002).
} 
home economy and remigration of the now more skilled workers, implying a transfer of physical and human capital to the weaker country. Additionally, after the migrated workers have reached a certain living standard, they are less willing to trade their families and specific amenities against more individual consumption. Higher living costs in the new world can further motivate remigration tendencies. If the inflowing capital is then spent on investment rather than consumption, the initially weaker economy achieves higher productivity growth rates than before. The country leaves its initial divergence path and moves to a process of economic convergence. This scenario is shown by Diagram $\mathrm{C}$ in Figure 3, in which $t_{1}$ marks the turning point after which convergence is achieved in the long run. For our analysis, it is important to know whether the countries under investigation are, on average, on a rather diverging or converging path. This is explored more closely in the subsequent section.

\section{Economic Convergence in the European Union}

\section{A. Concepts of economic convergence}

First introduced by Barro and Sala-i-Martin (1992), there exist two classical concepts of economic convergence: $\sigma$-convergence and $\beta$-convergence. Neoclassical growth theory suggests that economies with access to identical technologies should converge to a common income level. If the dispersion of wealth across economies is falling over time, this is called $\sigma$-convergence. As poorer economies usually show a higher marginal productivity of capital, they should grow faster in the transition to the long run steady state. If the poorer economies indeed show higher growth rates than the richer ones, there appears to be $\beta$-convergence. Unconditional $\beta$-convergence occurs when the economic gap between rich and poor economies decreases irrespective of economies' specific characteristics. That is, economic growth relies solely on the initial income level of the economy and is not conditioned on other factors. Conditional $\beta$-convergence, on the other hand, occurs when the dispersion of wealth becomes narrower over time between the economies that are similar in observable characteristics. Convergence in this case is conditional as it also depends on factors other than the initial income; e.g., investment, trade policies, institutions, or other specific circumstances. 
The two classical concepts are related in a way that $\beta$-convergence is a necessary condition for $\sigma$-convergence. If there is unconditional $\beta$-convergence, the cross-sectional variance is able to decrease over time. However, as conditional $\beta$-convergence may lead to multiple (economy or group-specific) equilibriums in the long run, the variation factor may also increase, leading to overall economic divergence in the long run. Moreover, an increase in the dispersion of wealth might even be possible in the case of unconditional $\beta$-convergence; i.e., when the initial dispersion of wealth is quite large and the average growth rates for the economies are quite similar. ${ }^{3}$ Hence, $\beta$-convergence is a necessary but not a sufficient condition for $\sigma$-convergence. As the two concepts of convergence are related to one another, both concepts are studied and applied empirically in the following sections.

\section{B. Testing for $\beta$-convergence}

\section{The case of unconditional convergence}

Following Baumol (1986), who first documented the existence of unconditional convergence on a sample of 16 industrial nations, where unconditional $\beta$-convergence is estimated by regressing the natural logarithm of the annual growth rate of real labour productivity for economy $i$ over a given period $T$ on the log of real labour productivity in the initial year $t_{0}$ of period $T$. The estimated equation then takes the form:

$$
\ln \left(\frac{y_{i, t_{0+T}}}{y_{i, t_{0}}}\right) \times\left(\frac{1}{\mathrm{~T}}\right)=\alpha+\beta \ln \left(y_{i, t_{0}}\right)+\varepsilon_{i, T}
$$

Here, $y_{i, t_{0+T}}$ refers to the value of real GDP per worker in the last year of period $T$ and refers to the value of real GDP per worker in the initial year of the period. The constant $\alpha$ is estimated in all regressions but not reported in the tables. $\varepsilon_{i, T}$ is the usual error term. According to theory, the $\beta$-coefficient should reveal a negative sign as poorer countries are expected to grow faster due to their longer distance to the long run steady state. ${ }^{4}$

\footnotetext{
${ }^{3}$ Consider the following example: two countries have an initial per capita income of $€ 20,000$ and $€ 40,000$ and a respective average growth rate of 3 and $2 \%$. The cross-sectional variance will then actually increase until period 30 despite the higher economic growth rate of the poorer country.

${ }^{4}$ Throughout the paper, this study uses data on GDP per worker for the measurement of economic growth because most formal growth models are based on production functions and their implications relate closely to labour productivity. More information on the data used in this study is given in Appendix 1.
} 
Table 1. Do poorer countries grow faster?

\begin{tabular}{|l|c|c|c|}
\hline & Cross-country & Pooled OLS & $\begin{array}{c}\text { Pooled OLS } \\
\text { w/ period effects }\end{array}$ \\
\hline \multirow{2}{*}{$G D P_{1993}$} & $-0.015^{* * *}$ & $-0.018^{* * *}$ & $-0.016^{* * *}$ \\
\hline Period effects & $(0.002)$ & $(0.004)$ & $(0.003)$ \\
\hline Adjusted R ${ }^{2}$ & - & - & Yes \\
\hline Number of observations & 0.70 & 0.39 & 0.53 \\
\hline
\end{tabular}

(Notes) (i) *,**, and *** denote significance at the $10 \%, 5 \%$, and $1 \%$ levels, respectively.

(ii) Standard errors in parentheses are robust to heteroskedasticity and serial correlation (i.e., clustered at the country level).

(iii) Coefficients (standard error) for period dummies: $-0.008(0.005)$ for period 2, $-0.004(0.003)$ for period 3, and -0.024 (0.005) for period 4. Base period: 1993 1997.

Table 1 indeed shows a strong tendency toward unconditional convergence across the EU member states over the period 1993 2012. The lower the income level at year 1993, the higher the country's economic growth rate. The first column is estimated as a standard cross-country regression comparable to that of Baumol (1986). The estimated effect is significantly different from zero at conventional levels of statistical significance and shows the expected negative sign. It reports a negative $\beta$-coefficient of $1.5 \%$, implying that an increase in a country's initial income per worker by $1 \%$ in 1993 reduces the average annual growth rate of the following 19 years by $1.5 \%$. In the second and third columns of Table 1, the number of observations is increased by applying Ordinary Least Squares (OLS) to a pooled regression of the panel. Using panel data allows capturing within-country variation over time. In order to lessen the issue of serial correlation in the transitory component of the disturbance term, our panel is split into five-year periods. The respective periods are 1993 1997, 1998 2002, 2003 2007, and 2008 2012. The initial level of income per worker and the average growth rate refer to the respective period. In both specifications, the $\beta$-coefficient is negative and statistically significant and only slightly higher than in the cross-country analysis. The third column shows the estimated $\beta$-coefficient under the assumption of fixed period effects. The included period dummies are expected to capture common shocks affecting aggregate production across the board. The relatively large and negative coefficient (standard error) of $-0.024(0.005)$ for the dummy referring to the period 2008 2012 indicates that time 
effects do matter in the sample and should be considered. Presumably, this time effect is mostly due to the Great Recession and the emerging European debt crisis that negatively affects economic growth in almost all European countries between 2008 and 2012. To sum up, the estimations presented in Table 1 point toward the existence of unconditional convergence. The coefficient of the initial level of income per worker is always negative and highly significant statistically. Depending on the specification, the estimated $\beta$-coefficient varies between 1.5 and $1.8 \%$.

To give a first impression whether country size might indeed be responsible for the convergence effect, column 3 of Table 1 has been re-estimated for the 21 small countries included in our sample. As this regression specification allows for withincountry variation over time, the estimated coefficient should be larger if the country size is the dominant factor. However, the $\beta$-coefficient (standard error) does not increase but slightly decreases to -0.015 (0.004), indicating that the size of a nation might not be relevant here. On the other hand, if only the twelve new EU member states are analyzed (of whom eleven are categorized as small states), the $\beta$-coefficient (standard error) increases to $-0.025(0.008)$, assuming that most of the convergence shown above is found due to the economic transition process of the new members. This argument is explored more closely at the end of this article.

\section{The case of conditional convergence}

Following the seminal empirical growth study by Mankiw et al. (1992), the neoclassical growth model developed by Solow (1956) and Swan (1956) serves as the reference model to test for conditional $\beta$-convergence. Here, the assumption of parameter homogeneity in the estimation of convergence equations is relaxed. Assuming positive and decreasing returns to capital, neoclassical growth theory suggests that the rates of saving and population growth determine the long run steady state of an economy. As the variables usually vary across economies, this leads to a situation where the economies reach different, either individual or group-specific, steady states. The standard CobbDouglas production is:

$$
Y=A K^{\alpha} L^{1-\alpha} \quad 0<\alpha<1
$$

Here, $Y$ is the output, $A$ the level of technology, $K$ the capital, and $L$ the labour. The

${ }^{5}$ See also Barro and Sala-i-Martin (1992) for a more detailed discussion. 
long run steady state stock of capital per effective unit of labour, $k^{*}$, can be derived as:

$$
k^{*}=\left(\frac{\mathrm{s}}{\mathrm{n}+\vartheta+\delta}\right)^{1 /(1-\alpha)}
$$

In this equation, the steady state capital-labour ratio is related positively to the savings rate $s$ and negatively to the rate of population growth $n$, the rate of technological progress $\vartheta$, and the rate of depreciation $\delta$. Inserting Equation (3) into the production function (2) and taking the natural logarithm, the long run steady state income per worker can be defined as:

$$
\ln \left(\frac{Y}{L}\right)=\ln (A)+\beta \ln (s)-\beta \ln (n+\vartheta+\delta)
$$

Here, $\beta$ equals $\alpha /(1-\alpha)$. As the Solow growth model treats technology as exogenously and equally distributed across the economies, $\ln (A)$ can be treated as constant. In order to see whether conditional $\beta$-convergence has occurred across the EU member states between 1993 and 2012, Equation (4) is rewritten as:

$$
\ln \left(\frac{y_{i, t_{0+T}}}{y_{i, t_{0}}}\right) \times\left(\frac{1}{\mathrm{~T}}\right)=\alpha+\beta_{1} \ln \left(y_{i, t_{0}}\right)+\beta_{2} \ln \left(s_{i, T}\right)+\beta_{3} \ln \left(n_{i, T}+\vartheta+\delta\right)+\varepsilon_{i, T}
$$

It is expected that the average economic growth depends negatively on the initial level of income per worker and the sum of population growth, technical progress, and capital depreciation, and positively on the savings rate. In line with De Long and Summers (1991), the savings rate $s$ is measured as the average share of real equipment investment in real GDP for economy $i$ over period $T$. By definition, the national current account is then balanced. The population growth rate $n$ is also averaged over period $T$. The rate of technological progress $\vartheta$ and the rate of depreciation $\delta$ are assumed to be identical across the economies and take the value 0.05 for each year and economy. Mankiw et al. (1992) and Islam (1995) assume this value to be reasonable for the sum of $\vartheta+\delta$. 
Table 2. Conditional convergence in neoclassical growth models

\begin{tabular}{|l|c|c|c|}
\hline & Cross-country & Pooled OLS & $\begin{array}{c}\text { Pooled OLS } \\
\text { with period effects }\end{array}$ \\
\hline GDP ${ }_{1993}$ & $\begin{array}{c}-0.011^{* * *} \\
(0.002)\end{array}$ & $\begin{array}{c}-0.013^{* * *} \\
(0.003)\end{array}$ & $\begin{array}{c}-0.012 * * * \\
(0.003)\end{array}$ \\
\hline Saving & $\begin{array}{c}0.207 * * \\
(0.103)\end{array}$ & $\begin{array}{c}0.126^{* * *} \\
(0.039)\end{array}$ & $\begin{array}{c}0.022 \\
(0.055)\end{array}$ \\
\hline Population growth & -0.148 & $-0.339^{*}$ & $-0.565 * * *$ \\
$(0.421)$ & $(0.184)$ & $0.195)$ \\
\hline Period effects & - & - & Yes \\
\hline Adjusted R ${ }^{2}$ & 0.74 & 0.47 & 0.56 \\
\hline Number of observations & 27 & 108 & 108 \\
\hline
\end{tabular}

(Notes) (i) *, **, and $* * *$ denote significance at the $10 \%, 5 \%$, and $1 \%$ levels, respectively.

(ii) Standard errors in parentheses are robust to heteroskedasticity and serial correlation. Coefficients (Standard error) for period dummies are $-0.008(0.005)$ for period $2,-0.003(0.003)$ for period 3 , and -0.024 (0.006) for period 4.

(iii) The base period is 1993 1997.

Table 2 reports the estimates of conditional $\beta$-convergence in neoclassical growth models. A negative coefficient is shown for the initial level of income per worker, which remains statistically significant throughout the regression specifications. Hence, conditional $\beta$-convergence seems to occur between the EU members. The average growth rate of saving shows the expected positive impact on economic growth and is mostly statistically significant. The same holds with the expected negative effect of population growth in combination with the rates of technical progress and depreciation.

An important extension of the neoclassical growth model, first explored empirically by Romer (1990) and Barro (1991), distinguishes human capital from physical capital. It is argued that human capital provides additional explanatory power with respect to economic growth. Identifying an empirically robust correlation between economic growth and human capital, however, turned out to be a difficult endeavour (Krueger and Lindahl 2001, De la Fuente and Doménech 2006). In order to give a more complete picture, we test if human capital should serve as an additional regressor to Equation (5) and if it changes conditional convergence. Education $E D U_{i, T}$ is used as a proxy for human capital; that is, persons with at least upper secondary educational attainment as a percentage share of the total working-age population (15 to 64 years). This leads to the following regression function: 


$$
\begin{aligned}
\ln \left(\frac{y_{i, t_{0+T}}}{y_{i, t_{0}}}\right) \times\left(\frac{1}{\mathrm{~T}}\right) & =\alpha+\beta_{1} \ln \left(y_{i, t_{0}}\right)+\beta_{2} \ln \left(s_{i, T}\right) \\
+ & \beta_{3} \ln \left(n_{i, T}+\vartheta+\delta\right)+\beta_{4} \ln \left(E D U_{i, T}\right)+\varepsilon_{i, T}
\end{aligned}
$$

The estimation results for the human capital augmented growth model are presented in Table 3. Human capital (education) seems to affect economic growth in the expected positive manner. In the pooled least squares specifications, the coefficient of educational attainment is statistically significant at the 1-percentage level. The coefficient of income per worker remains largely unaffected by model extensions, ranging between 1.2 and $1.4 \%$. In general, there seems to be evidence for $\beta$-convergence that is conditioned on country-specific factors other than the initial level of income per worker.

Table 3. Conditional convergence in human capital growth models

\begin{tabular}{|l|c|c|c|}
\hline & Cross-country & Pooled OLS & $\begin{array}{c}\text { Pooled OLS } \\
\text { with period effects }\end{array}$ \\
\hline GDP $_{1993}$ & $-0.012^{* * *}$ & $-0.014^{* * *}$ & $-0.013 * * *$ \\
\hline Saving & 0.167 & $0.120^{* * *}$ & 0.010 \\
\hline Population growth & -0.059 & -0.240 & $-0.450 * *$ \\
\hline Education & 0.102 & $0.145^{* * *}$ & $0.179^{* * *}$ \\
\hline Period effects & - & - & Yes \\
\hline Adjusted R & & 0.49 & 0.58 \\
\hline Number of observations & 27 & 108 & 108 \\
\hline
\end{tabular}

(Notes) (i) *,**, and *** denote significance at the $10 \%, 5 \%$, and $1 \%$ levels, respectively.

(ii) For clarity reasons, robust standard errors are not reported here but are available upon request. Coefficients (Standard error) for period dummies are $-0.009(0.005)$ for period 2, $-0.005(0.003)$ for period 3, and $-0.025(0.006)$ for period 4.

(iii) The base period is 1993 1997.

\section{Testing for $\sigma$-convergence}

Before turning to population size as a possible explanatory factor, the subsequent 
section illustrates whether the detected $\beta$-convergence has led to a decrease in the dispersion of wealth across the EU member states ( $\sigma$-convergence). In order to test for $\sigma$-convergence, the standard deviation of income per worker is estimated for each year.

Figure 4 shows to which extent there has been $\sigma$-convergence across the EU-27 member states between 1993 and 2012. The decline in the unweighted cross-sectional standard deviation of the log of real GDP per worker illustrates that the dispersion of wealth between the European economies gradually decreased over time. It fell roughly by $20 \%$, from 0.95 in 1993 to 0.70 in 2012 . $^{6}$ Only in 1999 and 2009 did there appear to be a slight increase in the overall declining path. These results are consistent with the findings of Kaitila (2014). It can be concluded that the $\beta$-convergence rate found in the previous section did, in fact, lead to $\sigma$-convergence across the EU member states. The next section investigates whether the size of a nation, i.e., population size, is partly responsible for the detected convergence effects.

\section{Figure 4. Income convergence among the $\mathrm{EU}$ member states}

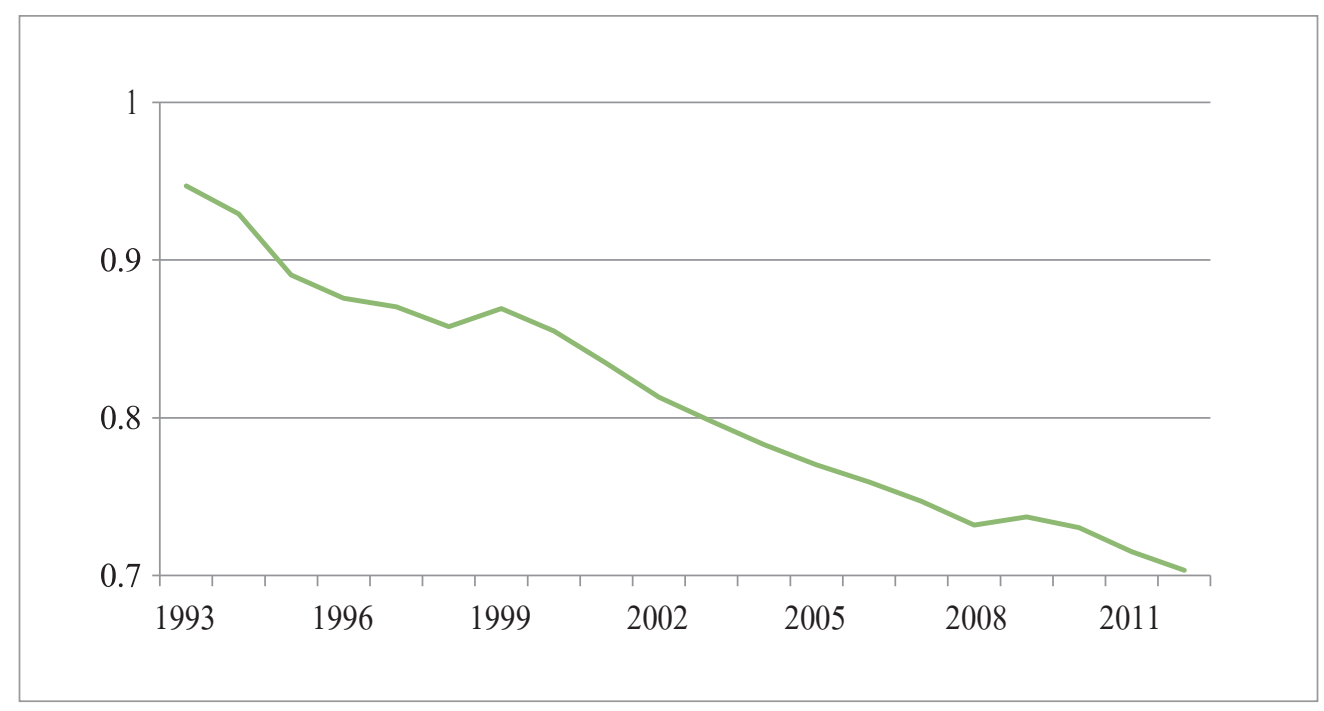

(Note) The figure shows the unweighted cross-sectional standard deviation of the natural logarithm of real GDP per worker (1993 2012) for the EU-27.

(Source) Eurostat database.

\footnotetext{
${ }^{6}$ As the average income in 2012 could be very much higher than in 1993, the shown $\sigma$-convergence between 1993 and 2012 might even be underestimated. When weighted with the arithmetic mean of the log of real GDP per worker in each year, however, it can be shown that this is not the case here. The dispersion of wealth is reduced by a very similar proportion: it fell from 0.093 in 1993 to 0.067 in 2012.
} 


\section{Effects of Country Size on Economic Growth}

\section{A. Main findings}

Based on the findings of the previous section, the human capital augmented growth model serves as the baseline model. In order to test for a distinct size effect in economic growth, population size $P O P_{i, t_{0}}$ is included into the baseline Equation (6), leading to:

$$
\ln \left(\frac{y_{i, t_{0+T}}}{y_{i, t_{0}}}\right) \times\left(\frac{1}{\mathrm{~T}}\right)=\alpha+\beta_{1} \ln \left(P O P_{i, t_{0}}\right)+\beta_{2} \ln \left(y_{i, t_{0}}\right)+\beta_{3} V 1_{i, T}+\varepsilon_{i, T}
$$

The natural logarithm of population $P O P_{i, t_{0}}$ is measured at the initial year of each period. Five-year periods are used as in the previous section. The initial income per worker, as well as the variables behind the human capital augmented growth model summarized by vector $V 1_{i, T}$, serves as control variable. The estimated standard errors are robust to arbitrary heteroskedasticity and serial correlation, i.e., they are clustered at the country level (Wooldridge 2010).

Column 1 of Table 4 shows that the estimated impact of population size on economic growth is significantly different from zero at conventional levels of statistical significance and shows the expected negative sign. The result implies that a country whose population is increased by $1 \%$ in 1993 reduces its average annual economic growth rate by $0.3 \%$. Initial income per worker, as well as the control variables, also shows the expected signs and are statistically significant. However, omitted variable bias can be of serious concern if all relevant factors are not considered. As demonstrated by Wooldridge (2010), omitted variables are lumped into the error term and yield biased and inconsistent estimates. Hence, the regression should include more relevant factors. The open-ended capacity of economic growth theory, though, admits a broad number of logical and testable control variables. In fact, the Durlauf et al. (2005) survey of empirical growth literature identifies 43 distinct growth theories and a total of 145 significant regressors. Building on the seminal work of Levine and Renelt (1992) and Sala-i-Martin et al. (2004), Moral-Benito (2012a and 2012b) addresses the problem of model uncertainty using Bayesian Model Averaging (BMA). This method tackles the issue of model uncertainty and identifies the most robust growth determinants empirically. The basic idea of BMA is to make inferences based on weighted averages 
over model space, thereby accounting for model uncertainty in parameter estimates through probabilities within a Bayesian framework. As we apply a highly similar model specification, our choice of control variables depends on the two studies by Moral-Benito (2012a and 2012b). In addition to the population size, initial income, and regressors of vector $V 1_{i, T}$, the following variables are considered as additional control variables: trade openness (imports plus exports as a share of GDP), investment price level (as a proxy for the level of distortions of market prices in the economy), the ratio of government consumption to GDP (as it could lower saving and growth through the distorting effects from taxation or government-expenditure programs), and the role of a secure investment environment. ${ }^{7}$ These additional variables are combined in vector $V 2_{i, T}$.

Table 4. Effects of country size on economic growth

\begin{tabular}{|l|c|c|c|c|}
\hline & Pooled OLS & Pooled OLS & Fixed Effects & $\begin{array}{c}\text { Instrumental } \\
\text { Variables }\end{array}$ \\
\hline Population $_{1993}$ & $-0.003^{* * *}$ & $-0.002^{*}$ & -0.029 & -0.064 \\
\hline GDP $_{1993}$ & $-0.011^{* * *}$ & $-0.005^{*}$ & $-0.069^{* * *}$ & $-0.078^{* * *}$ \\
\hline Saving & 0.018 & -0.036 & $-0.080^{* *}$ & $-0.081^{* * *}$ \\
\hline Population growth & $-0.626^{* * *}$ & $-0.920^{* * *}$ & $-0.826^{* *}$ & $-0.803^{* * *}$ \\
\hline Education & $0.224^{* * *}$ & $0.190^{* * *}$ & -0.009 & -0.003 \\
\hline Openness & & $-0.190^{* *}$ & -0.128 & -0.120 \\
\hline Investment & & 0.064 & 0.013 & 0.011 \\
\hline Government consumption & & -0.078 & -0.055 & -0.055 \\
\hline FDI & & $0.047 *$ & 0.023 & 0.022 \\
\hline Period effects & & Yes & Yes & Yes \\
\hline Adjusted R ${ }^{2}$ & Yes & 0.71 & 0.70 & 0.70 \\
\hline Number of observations & 108 & 108 & 108 & 108 \\
\hline
\end{tabular}

(Notes) (i) *, **, and $* * *$ denote significance at the $10 \%, 5 \%$, and $1 \%$ levels, respectively.

(ii) For clarity reasons, robust standard errors are not reported here but are available upon request.

(iii) In the instrumental variable regression, population is instrumented by the country's land area and by a five-year lag of population.

\footnotetext{
${ }^{7}$ To test the investment environment, this study uses foreign direct investments. The typical polity measures (e.g. corruption, economic freedom) are too homogeneous across the EU member states. Inward stocks of FDI, on the other hand, show much more variation.
} 
Column 2 of Table 4 illustrates that the inclusion of additional control variables reduces the statistical significance of the population effect. However, adding more control variables also increases the risk of multicollinearity. One test for identifying multicollinearity is the Variance Inflation Factor (VIF). The square root of the VIF is able to detect an increase in standard errors compared to the ideal situation of completely uncorrelated independent variables. According to O`Brien (2007), the VIF should not exceed the factor of 10. In our sample, the VIF of the independent variables varies from 1.18 to 3.18. Multicollinearity is, therefore, not a problem here.

The loss of the statistical significance of population size is further confirmed by estimating fixed-effects and instrumental variable regressions, as presented in Columns 3 and 4 of Table 4 . The statistical significance of population even disappears once the model is specified to control for country-specific fixed effects. The same holds when possible endogeneity issues are considered by using instrumental variable regressions. Endogeneity might appear through simultaneous causation between population and economic growth, as worker migration might also be influenced by the economic situation in the home country. Similar to Rose (2006), we address the potential for endogeneity bias by using a country's land area as an instrumental variable. As a second instrument, the (five-year) lag of population is used. The test statistics presented in Appendix 2 indicate that these are valid instruments. As can be seen from Column 4 of Table 4, population still remains statistically insignificant.

As a further robustness check, annual data is used instead of five-year periods. The dependent variable then becomes the actual annual growth rate of per worker income at time $t$. Accordingly, the issue of endogeneity is becoming larger. In order to again account for a possible endogeneity bias, the independent variables are estimated with lagged values. Table 5 illustrates that in both regression specifications (with and without additional control variables), population remains statistically insignificant. This holds for the fixed effects estimations, as well as for the instrumental variable regressions.

Using annual regressions has the additional benefit to test for an entry effect of EU and EMU on economic growth. The dummy turns from 0 to 1 if the country is becoming a member of the union. The estimated coefficient of the EU dummy is positive and statistically significant. This indicates, ceteris paribus, that entry into the EU increases economic growth. This result further confirms the initial assumption of this paper that countries in general benefit from further market integration as membership in the EU offers free access to its large internal market. The empirical 
study by Crespo-Cuaresma et al. (2008) confirms this study's result as they find a positive effect of a country's length of EU membership on economic growth. ${ }^{8}$ On the contrary, the respective dummy controlling for EMU membership yields neither positive nor significant results. Assumingly, this might be due to the weak change in relative price elasticity that the EMU members have experienced after the launch of the euro as demonstrated by Holtemöller and Zeddies (2013).

Table 5. Impact of EU and EMU membership on economic growth

\begin{tabular}{|l|c|c|c|c|}
\hline & Fixed effects & Fixed effects & $\begin{array}{c}\text { Instrumental } \\
\text { variables }\end{array}$ & $\begin{array}{c}\text { Instrumental } \\
\text { variables }\end{array}$ \\
\hline Population $_{t-1}$ & -0.088 & -0.089 & -0.095 & -0.096 \\
\hline$G D P_{t-1}$ & $-0.156^{* * *}$ & $-0.163^{* * *}$ & $-0.157^{* * *}$ & $-0.164^{* * *}$ \\
\hline$E U_{i, t}$ & $0.016^{* * *}$ & $0.014 * *$ & $0.016^{* * *}$ & $0.014 * * *$ \\
\hline$E M U_{i, t}$ & -0.005 & -0.004 & -0.005 & -0.004 \\
\hline $\ln \left(V 1_{i, t-1}\right)$ & Yes & Yes & Yes & Yes \\
\hline $\ln \left(V 2_{i, t-1}\right)$ & - & Yes & - & Yes \\
\hline Year effects & Yes & Yes & Yes & Yes \\
\hline Within /centred R & 0.33 & 0.34 & 0.33 & 0.34 \\
\hline Number of observations & 513 & 513 & 513 & 513 \\
\hline
\end{tabular}

(Notes) (i) *, **, and *** denote significance at the $10 \%, 5 \%$, and $1 \%$ levels, respectively.

(ii) For clarity reasons, robust standard errors are not reported here but are available upon request.

(iii) Population is instrumented by the country's land area and the annual lag of population.

\section{B. Multiple transition periods}

The above shown results could also be due to the coexistence of significant forces that outweigh each other (Badinger and Breuss 2006). For instance, it is quite reasonable to believe that the integration effects are more beneficial to a country in the years surrounding its entry date. After a certain threshold, the convergence process could

\footnotetext{
${ }^{8}$ For the general role of political factors in explaining the dynamics of growth transitions, see Sen (2013)
} 
even lead to a process of economic divergence due to prevailing market imperfections in the common market. In the case of an incomplete market, the larger countries can compensate for market imperfections relatively better because of increasing returns. Likewise, large countries could have an advantage when passing the different stages of accession to the EU. Although pre-accession assistance is usually provided to each candidate country, small economies would still be more vulnerable to exogenous shocks if the financial assistance provided by the EU is not sufficient.

Diagram A in Figure 5 illustrates such an example with prevailing market imperfections and/or the countries' different accession stasges to the EU. Here, after a certain period, economic divergence occurs and implies that convergence is not achieved in the end. Depending on whether most of the sample countries are placed on the left or right of the turning point, the respective coefficient of population in a regression output is positive, negative, or even insignificant. This may partly explain the mixed results from the empirical evidence presented in previous studies: Easterly and Kraay (2000) showing negative effects, Alesina et al. (2005) showing positive effects, and Badinger and Breuss (2006) and Rose (2006) demonstrating insignificant effects of country size on economic growth.

Figure 5. Extending the scenarios of economic convergence

a) Divergence after convergence

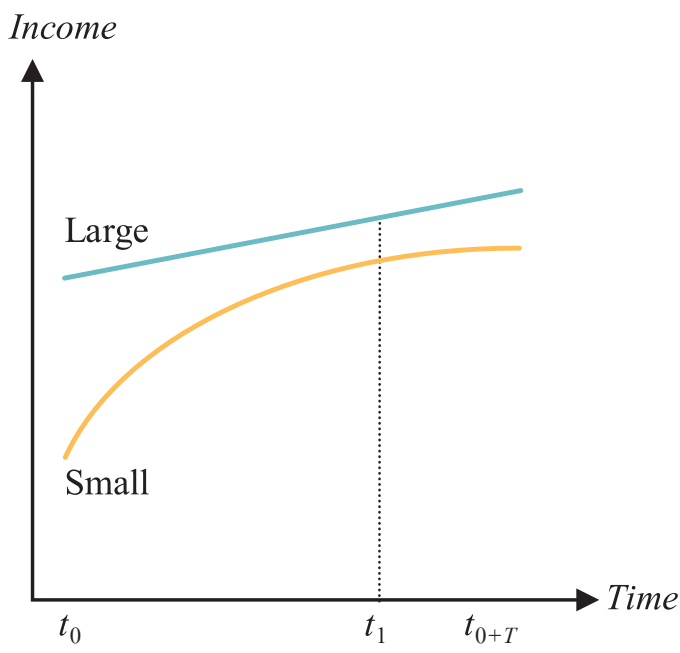

${ }^{9}$ For a recent overview of the economic effects on new members, see Jovanovic and Damnjanovic (2014). 


\section{b) Convergence with multiple transitions}

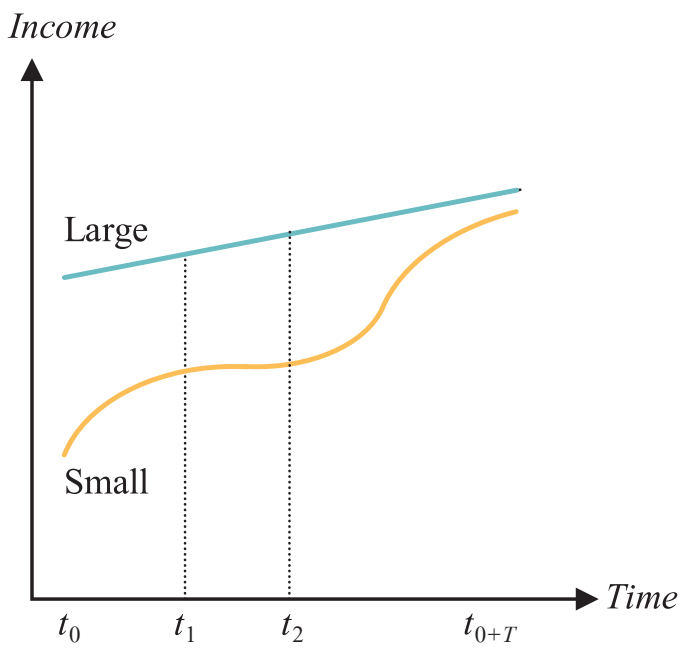

\section{c) Convergence with 'overshooting'}

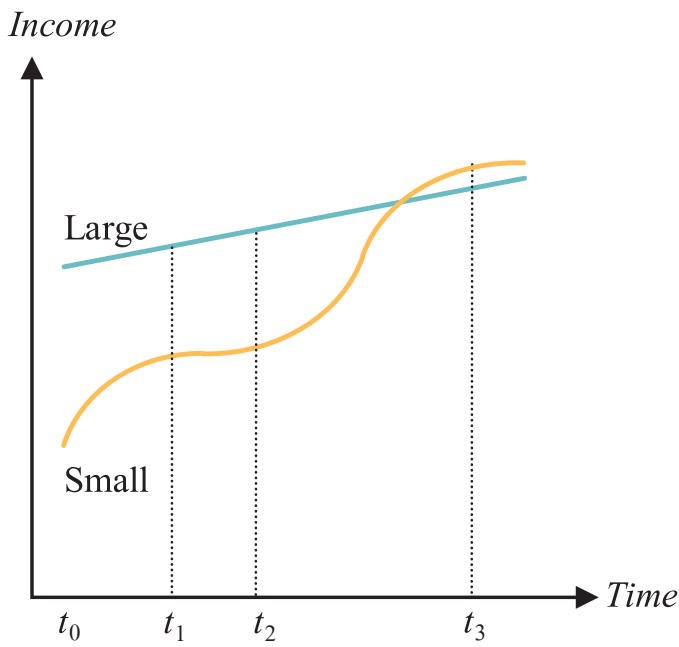

(Note) The scenarios illustrated here extend the scenarios of economic convergence and divergence shown in Figure 3. In congruence with the empirical results presented in Table 7, Diagram C of Figure 5 is expected to display the most realistic scenario for the current case of EU integration (1993 2012).

In congruence with our empirical results, however, it is more likely that convergence is achieved in end and that the convergence path is characterized by multiple transitory turning points. In Diagram B, several periods of converging and diverging effects 
mark the long-term convergence path due to different nonlinear stages of economic integration. Here, the insignificant effect of population on growth found in the previous section might be due to the fact that our country sample is very heterogeneous in terms of the countries' economic integration level. This implies that analyzing a more homogeneous country sample could yield statistically significant results. Hence, splitting our sample countries into specific groups, in which the countries are expected to have more homogeneous integration levels, should provide some empirical clarity. For this purpose, the older EU members EU-15 are combined in one group and the 12 new member states that joined the EU in 2004 and 2007 form a second country group. ${ }^{10}$

Table 6. Population effects of Old and New members

\begin{tabular}{|l|c|c|c|c|}
\hline & \multicolumn{2}{|c|}{ Old members } & \multicolumn{2}{c|}{ New members } \\
\cline { 2 - 5 } & Fixed Effects & $\begin{array}{c}\text { Instrumental } \\
\text { Variables }\end{array}$ & Fixed Effects & $\begin{array}{c}\text { Instrumental } \\
\text { Variables }\end{array}$ \\
\hline Population $_{\mathrm{t}-1}$ & $0.215^{*}$ & $0.219^{* *}$ & $-0.325^{* *}$ & $-0.336^{* * *}$ \\
\hline$G D P_{\mathrm{t}-1}$ & $-0.203^{* * *}$ & $-0.203^{* * *}$ & $-0.289^{* * *}$ & $-0.291 * * *$ \\
\hdashline$L n\left(V 1_{i, t-1}\right)$ & Yes & Yes & Yes & Yes \\
\hline Year effects & Yes & Yes & Yes & Yes \\
\hline Within/centred $\mathrm{R}^{2}$ & 0.44 & 0.44 & 0.41 & 0.41 \\
\hline Number of observations & 285 & 285 & 228 & 228 \\
\hline
\end{tabular}

(Notes) (i) *,**, and $* * *$ denote significance at the $10 \%, 5 \%$, and $1 \%$ levels, respectively.

(ii) For clarity reasons, robust standard errors are not reported here but are available upon request.

Table 6 reveals very interesting results in that regard. First, population seems to matter for both country groups. Second, the direction of the population effect on economic growth is different between the two groups. Whereas for the new members being a small country is more beneficial in terms of economic growth, the old members show the opposite result while the large and not the small countries seem to grow economically faster. The same substantive results are obtained when the control variables of vector $V 2_{i, t-1}$ are incorporated into the model and when five-year periods are

\footnotetext{
${ }^{10}$ As demonstrated by König (forthcoming), the cluster analysis of the EU-27 shows that the old member states are generally more integrated into the EU than the new member states.
} 
used instead of annual data. ${ }^{11}$ As the effect is less intense for the old and more integrated member states, this might imply that the population effect seems to decrease as market integration increases. Thus, it is reasonable to believe that the two population effects might outweigh each other and lead to overall insignificant results when the regressions are estimated without splitting the sample into feasible country groups.

According to Diagram $\mathrm{C}$ of Figure 5, the new members would lie somewhere between $t_{0}$ and $t_{1}$. Given the longer membership of the EU-15 countries and their experienced integration effects, they should be placed closer to the steady state and to the right of the new member states. In fact, the data confirms this assumption by showing much higher average per worker income levels for the small EU-15 countries (roughly $€ 62,000)$ than for the small new member states $(€ 17,000)$ in 2012.

As the separate regressions of both country groups yield negative initial GDP effects, i.e., economic convergence, it is less plausible to believe that the EU-15 countries might be on a temporary divergence path between $t_{1}$ and $t_{2}$. It is more likely that the small EU-15 countries have exceeded the average per worker income level of their larger counterparts in the light of increased economic integration. The convergence process then restarts after $t_{3}$, in which over- and undershooting the common convergence path (e.g., due to fluctuations in the investment levels) could be a natural process along the long run steady state of the EU member states. The descriptive data also confirms this assumption. In 1993, the average income per worker was higher in the large EU-15 countries, whereas in 2012, the average income level of the small EU-15 countries was higher.

\section{Conclusion}

The last enlargement rounds of the European Union considerably increased the number of small EU member states. Hence, it is important to investigate whether EU membership contains a certain small country bonus and whether such a finding promotes the desired economic convergence process of the member states.

By investigating the EU-27 over the period 1993 to 2012, it is shown that $\beta$-convergence, as well as $\sigma$-convergence, exists. Countries with lower initial income

\footnotetext{
${ }^{11}$ Not reported here but available upon request.
} 
grow faster than the more advanced countries, whereas income levels tend to converge in the long run. It is further shown that, ceteris paribus, a smaller population size positively affects economic growth. This tends to confirm the intuition that in the long run, free access to the EU Single Market provides an effective means of evading the initial penalties of smallness.

However, the clarity of the population effect blurs once more when control variables are included in the regressions. The effect even turns out to be statistically insignificant when controlling for country-specific fixed effects. Only then do initial income and the standard variables of neoclassical growth theory seem to matter for economic success. The same results hold for the instrumental variable regressions that deal with issues of endogeneity.

Yet, this finding does not clearly imply that population has no significant effect on economic growth at all. It could also be the case that the statistically insignificant coefficient arises from opposite but significant effects that partially outweigh each other. As the economic transition process of the EU member states might be characterized by multiple turning points, different EU integration levels of the members may distort the detection of a clear effect. As different economic integration levels imply different growth effects, this could bias the regression results. This is especially the case when a heterogeneous community such as the EU-27 is investigated jointly by one regression. By splitting the sample into two groups of old and new members, this study shows that the population effect indeed remains statistically significant even after controlling for country-specific fixed effects, additional control variables, and endogeneity issues.

The following policy implications can be derived from these findings:

- As prevailing market imperfections disproportionately penalise small countries, the EU should quickly remove all technical barriers to trade within the EU Single Market. The services section is especially affected. The Single Market Acts I and II presented by the Commission in 2011 and 2012, respectively, can be considered as steps moving to the right direction. However, since 2012 the process has slowed down. The Commission should therefore accelerate this process.

- The Instrument for Pre-Accession Assistance (IPA) should be extended by programs that assist especially the needs of small candidate countries. Thereby, not only financial assistance but also technical expertise should flow to the small countries and their export oriented firms. This could essentially improve market efficiency during the first years of EU accession and could even multiply the small 
country bonus.

- In order to overcome the impediments of smallness, the small new member states should try to attract Foreign Direct Investments (FDIs). FDIs should attract Greenfiled investments that respect the special needs of a small economy; i.e., physical and human capital. A closer coordination between a country's innovation policy and investment promotion is therefore needed.

- Additionally, the EU, as well as national governments, should invest more in research and development projects in order to raise human capital. This is of utmost importance for small economies due to their limited factor endowments. The empirical results presented in this and other studies suggest that human capital; i.e., education, serves as a good catalyst for economic growth. The EU programme Horizon 2020 with a funding of nearly 80 billion Euros is a good start that needs to attract further private investment.

- As the new member states still face per capita income levels that are far below the EU-average, the European Commission might revise its Cohesion Policy to induce sustainable growth. As noted by Marzinitto (2012), standard income convergence analysis is not sufficient for a qualitative assessment and should be accompanied by an assessment of the changes in the efficiency of the capital stock. The EU should implement a monitoring scheme that is also based on qualitative assessments.

- As the results also show that European economic integration positively affects economic growth, it is important to monitor the integration efforts of the member states. The Internal Market Scoreboard and the Macroeconomic Imbalance Procedure of the European Commission could be complemented by the EU Index developed by König and Ohr (2013), which covers many relevant aspects of EU integration on a yearly basis.

To sum up, the results imply that further integration steps, such as the elimination of barriers to trade or an extensive reduction of the home bias effect, are needed. This would eventually lead to an economic union, in which the size of a country becomes less relevant for its economic success. Hence, the completion of the EU Single Market should be at the forefront of future European integration processes, especially with regard to the large and increasing number of small EU member states. 


\section{References}

Alesina, Alberto, and Enrico Spolaore. The Size of Nations. Cambridge: MIT Press, 2003.

Alesina, Alberto, Spolaore, Enrico, and Romain Wacziarg. "Trade, Growth and the Size of Countries." In Handbook of Economic Growth, Volume 1B, edited by Philippe Aghion and Steven N. Durlauf, 1499-1542. Amsterdam: North-Holland, 2005.

Armstrong, Harvey W., and Robert Read. "The Determinants of Economic Growth in Small States." The Round Table 368 (2003): 99-124.

Badinger, Harald, and Fritz Breuss. "Country Size and the Gains from Trade Bloc Enlargement: An Empirical Assessment for the European Community." Review of International Economics 14 (2006): 615-631.

Badinger, Harald, and Fritz Breuss. "Country Size and the Trade Effects of the Euro." Review of World Economics 145 (2009): 207-223.

Balta, Narcissa, and Juan Delgado. "Home Bias and Market Integration in the EU." CESifo Economic Studies 55 (2009): 110-144.

Barro, Robert J. "Economic Growth in a Cross Section of Countries." Quarterly Journal of Economics 106 (1991): 407-443.

Barro, Robert J., and Xavier Sala-i-Martin. "Convergence." Journal of Political Economy 100 (1992): 223-251.

Barro, Robert J., and Xavier Sala-i-Martin. "Economic Growth.” Cambridge: MIT Press, 2004.

Baumol, William J. "Productivity Growth, Convergence, and Welfare: What the Longrun Data Show." American Economic Review 76 (1986): 1072-1085.

Casella, Alessandra. "Large Countries, Small Countries and the Enlargement of Trade Blocs.” European Economic Review 40 (1996): 389-415.

Crespo-Cuaresma, Jesus, Ritzberger-Grünwald, Doris, and Maria A. Silgoner. "Growth, Convergence and EU Membership.” Applied Economics 40 (2008): 643-656.

De la Fuente, Angel, and Rafael Doménech. "Human Capital in Growth Regressions: How Much Difference Does Data Quality Make?" Journal of the European Economic 
Association 4 (2006): 1-36.

De Long, James B., and Lawrence H. Summers. "Equipment Investment and Economic Growth.” Quarterly Journal of Economics 106 (1991): 445-502.

De Mello, Luiz R. "Foreign Direct Investment-led Growth: Evidence from Time Series and Panel Data." Oxford Economic Papers 51 (1999): 133-151.

Durlauf, Steven N., Johnson, Paul A., and Jonathan R.W. Temple. "Growth Econometrics." In Handbook of Economic Growth, Volume 1A, edited by Philippe Aghion and Steven N. Durlauf, 555-667. Amsterdam: North-Holland, 2005.

Easterly, William, and Aart Kraay. "Small States, Small Problems? Income, Growth, and Volatility in Small States.” World Development 28 (2000): 2013-2027.

Furceri, Davide, and Georgios Karras. "Country Size and Business Cycle Volatility: Scale Really Matters." Journal of the Japanese and International Economies 21 (2007): 424-434.

Holtemöller, Oliver, and Götz Zeddies. "Has the Euro Increased International Price Elasticities?" Empirica 40 (2013): 197-214.

Howarth, D., and T. Sadeh, eds. "The Political Economy of Europe's Incomplete Single Market." London: Routledge, 2011.

Jovanovic, Miroslav N., and Jelena Damnjanovic. "EU Eastern Enlargement: Economic Effects on New Members 2000 2012.” Journal of Economic Integration 29 (2014): 210243.

Kaitila, Ville. "Transnational Income Convergence and National Income Disparity: Europe, 1960 2012.” Journal of Economic Integration 29 (2014): 343-371.

König, Jörg. "The EU Index of Integration Effort." In Indicator-based Monitoring of Regional Economic Integration, edited by Philippe De Lombaerde. United Nations University Series on Regionalism: Springer, forthcoming.

König, Jörg, and Renate Ohr. "Different Efforts in European Economic Integration: Implications of the EU Index." Journal of Common Market Studies 51 (2013): 10741090 .

Krueger, Alan B., and Mikael Lindahl. "Education for Growth: Why and for Whom?" Journal of Economic Literature 39 (2001): 1101-1136. 
Krugman, Paul R. "Increasing Returns and Economic Geography." Journal of Political Economy 99 (1991): 483-499.

Levine, Ross, and David Renelt. "A Sensitivity Analysis of Cross-country Growth Regressions." American Economic Review 82 (1992): 942-963.

Lucas, Robert E. "On the Mechanics of Economic Development." Journal of Monetary Economics 22 (1988), 3-42.

Mankiw, N. Gregory, Romer, David, and David N. Weil. "A Contribution to the Empirics of Economic Growth." Quarterly Journal of Economics 107 (1992): 407-437.

Marzinotto, Benedicta. "The Growth Effects of EU Cohesion Policy: A Meta-analysis." Bruegel Working Paper 14 (2012): 1-22.

Moral-Benito, Enrique. "Determinants of Economic Growth: A Bayesian Panel Data Approach." Review of Economics and Statistics 94 (2012): 566-579.

Moral-Benito, Enrique. "Growth Empirics in Panel Data under Model Uncertainty and Weak Exogeneity." Journal of Applied Econometrics (2014).

O’Brien, Robert M. “A Caution Regarding Rules of Thumb for Variance Inflation Factors." Quality and Quantity 41 (2007), 673-690.

Pacchioli, Consuelo. "Is the EU Internal Market Suffering from an Integration Deficit? Estimating the 'Home-bias Effect'." CEPS Working Document 348 (2011): 1-27.

Robinson, Edward A.G., ed. "Economic Consequences of the Size of Nations." New York, NY: Macmillan, 1960.

Romer, Paul M. "Increasing Returns and Long-run Growth." Journal of Political Economy 94 (1986): 1002-1037.

Romer, Paul M. "Endogenous Technological Change." Journal of Political Economy 98 (1990): S71-S102.

Rose, Andrew K. "Size Really Doesn't Matter: In Search of a National Scale Effect." Journal of the Japanese and International Economies 20 (2006): 482-507.

Sala-i-Martin, Xavier. "The Classical Approach to Convergence Analysis." Economic Journal 106 (1996): 1019-1036.

Sala-i-Martin, Xavier, Doppelhofer, Gernot, and Ronald I. Miller. "Determinants of 
Long-term Growth: A Bayesian Averaging of Classical Estimates (BACE) Approach.” American Economic Review 94 (2004): 813-835.

Scitovsky, Tibor. "International Trade and Economic Integration as a Means of Overcoming the Disadvantages of a Small Nation." In Economic Consequences of the Size of Nations, edited by Edward A.G. Robinson, 282-290. London: Macmillan, 1960.

Sen, Kunal. "The Political Dynamics of Economic Growth." World Development 47 (2013): 71-86.

Solow, Robert M. "A Contribution to the Theory of Economic Growth.” Quarterly Journal of Economics 70 (1956): 65-94.

Swan, Trevor W. "Economic Growth and Capital Accumulation." Economic Record 32 (1956): 334-361.

Tabuchi, Takatoshi, and Jacques-Francois Thisse. "Taste Heterogeneity, Labor Mobility and Economic Geography." Journal of Development Economics 69 (2002): 155-177.

Veeramani, C. "World's Knowledge Spillovers: Beyond Openness and Growth." Journal of Economic Integration 29 (2014): 298-328.

Wooldridge, Jeffrey M. "Econometric Analysis of Cross Section and Panel Data." Cambridge, MA: MIT Press, 2010.

Zimmermann, Klaus F. "Labor Mobility and the Integration of European Labor Markets." IZA Discussion Papers 3999 (2009): 1-22. 


\section{Appendices}

\section{Appendix 1: Definition of variables and data sources}

\begin{tabular}{|c|c|c|}
\hline Variable & Description & Source \\
\hline$\left(\frac{1}{T}\right) \times \ln \left(\frac{y_{i, t_{0+T}}}{y_{i, t_{0}}}\right)$ & $\begin{array}{l}\text { Average annual growth rate of income per worker for } \\
\text { economy } i \text { over period } T\end{array}$ & $\begin{array}{l}\text { Eurostat } \\
\text { http://epp.eurostat.ec.europa.eu }\end{array}$ \\
\hline $\ln \left(y_{i, t_{0}}\right)$ & $\begin{array}{l}\text { Initial income per worker. Measured as the natural } \\
\text { logarithm of real GDP (chain weighted } 2005 \text { prices) } \\
\text { per worker (age 15-64). In the simple cross-country } \\
\text { regressions, initial income refers to 1993. In the five-year } \\
\text { pooled regressions, initial income refers to } 1993,1998 \text {, } \\
\text { 2003, and 2008. In the panel regressions with annual data, } \\
\text { initial income and all other independent variables are } \\
\text { lagged by one year. }\end{array}$ & Eurostat \\
\hline $\ln \left(s_{i, t}\right)$ & $\begin{array}{l}\text { Savings rate. Measured as the natural logarithm of the } \\
\text { average share of real equipment investment in real GDP } \\
\text { for economy } i \text { over period } T \text {. }\end{array}$ & Eurostat \\
\hline $\ln \left(n_{i, T}+\vartheta+\delta\right)$ & $\begin{array}{l}\text { Sum of the rates of population growth, capital } \\
\text { depreciation, and technological progress. The rates of } \\
\text { technological progress and depreciation take jointly the } \\
\text { value } 0.05 \text { for each year and country (see Mankiw et al., } \\
1992 \text { and Islam, 1995). }\end{array}$ & Eurostat \\
\hline $\ln \left(P O P_{i, t_{0}}\right)$ & $\begin{array}{l}\text { Natural logarithm of population on January } 1 \text { of each year } \\
\text { or period }\end{array}$ & Eurostat \\
\hline $\ln \left(E D U_{i, T}\right)$ & $\begin{array}{l}\text { Persons with upper secondary or tertiary education } \\
\text { attainment per working age population (age 15-64) }\end{array}$ & Eurostat \\
\hline $\ln \left(O P E N_{i, T}\right)$ & $\begin{array}{l}\text { Openness in trade. Measured as the natural logarithm of } \\
\text { the average share of the sum of exports and imports of } \\
\text { total trade in goods and services in real GDP. }\end{array}$ & Eurostat \\
\hline $\ln \left(P R I C E_{i, T}\right)$ & Price level of investment & $\begin{array}{l}\text { Penn World Table } \\
\text { http://www.ggdc.net/pwt }\end{array}$ \\
\hline $\ln \left(G O V_{i, T}\right)$ & Government expenditure as a percentage of GDP & Eurostat \\
\hline $\ln \left(F D I_{i, T}\right)$ & $\begin{array}{l}\text { Stocks of inward Foreign Direct Investments (FDI) as a } \\
\text { percentage of GDP }\end{array}$ & $\begin{array}{l}\text { OECD, UNCTAD } \\
\text { http://stats.oecd.org } \\
\text { http://unctadstat.unctad.org }\end{array}$ \\
\hline $\ln \left(V 1_{i, T}\right)$ & $\begin{array}{l}\text { The variables of the human capital growth model: } \\
\text { savings rate, sum of the rates of population growth, capital } \\
\text { depreciation and technological progress, and education. }\end{array}$ & See above \\
\hline $\ln \left(V 2_{i, T}\right)$ & $\begin{array}{l}\text { Additional control variables: openness, investment, } \\
\text { government consumption, and FDI stocks. }\end{array}$ & See above \\
\hline
\end{tabular}




\section{Appendix 2: Test statistics for instruments}

\begin{tabular}{|l|l|r|r|}
\hline \multicolumn{1}{|c|}{ Test } & \multicolumn{1}{|c|}{ Description } & $\begin{array}{c}\text { Five-year data } \\
\text { regression }\end{array}$ & \multicolumn{1}{c|}{$\begin{array}{c}\text { Annual data } \\
\text { regression }\end{array}$} \\
\hline Instrumented variable & Population & & \\
\hline Excluded instruments & Lag of population; land area & & \\
\hline Underidentification test & Kleibergen-Paap rk LM statistic & $p$-value $=0.02$ & $p$-value $=0.01$ \\
\hline Weak identification test & Cragg-Donald Wald F statistic & 110.15 & $4.7 \mathrm{e}+04$ \\
\hline & Kleibergen-Paap Wald rk F statistic & 68.66 & $2.5 \mathrm{e}+04$ \\
\hline Weak-instrument inference & Anderson-Rubin-Wald test & $p$-value $=0.23$ & $p$-value $=0.47$ \\
\hline & Stock-Wright LM S statistic & $p$-value $=0.16$ & $p$-value $=0.45$ \\
\hline Overidentification test & Hansen J statistic & $p$-value $=0.52$ & $p$-value $=0.68$ \\
\hline Endogeneity test & endog option & $p$-value $=0.04$ & $p$-value $=0.12$ \\
\hline
\end{tabular}

(Note) Statistics are robust to heteroskedasticity and clustering on countries. Dependent variable is economic growth. Independent variables are population, initial income, vector $V 1$ variables, and time dummies. 